\title{
Peak flow rate in relation to forced expiratory volume in hemp workers
}

\author{
E. ŽU '̌́SKIN and F. VALIĆ \\ Department of Occupational Health, Andrija Stampar School of Public Health, \\ Medical Faculty, Zagreb University, Zagreb, Yugoslavia
}

\begin{abstract}
Žuškin, E., and Valić, F. (1971). Brit. J. industr. Med., 28, 159-163. Peak flow rate in relation to forced expiratory volume in hemp workers. Measurements of the forced expiratory volume in one second $\left(\mathrm{FEV}_{1.0}\right)$ and the peak expiratory flow rate (PEF) were made in 99 non-smoking female hemp workers before and after the shift. A significant mean reduction of both FEV $_{1.0}$ and PEF $(P<0.01)$ over the shift was found in workers both with and without byssinosis but the relative reductions of PEF were more pronounced (FEV F. $_{1.0} 15 \cdot 3 \%$; PEF $20.8 \%)$. There was a significant positive correlation $(P<0.01)$ both between absolute $\mathrm{FEV}_{1.0}$ and PEF values measured before work (with byssinosis $r=0.605$; without byssinosis $r=0.461$ ), and between $\mathrm{FEV}_{1.0}$ and PEF changes over the shift (with byssinosis $r=0.725$; without byssinosis $r=0.631$ ). There was also a significant correlation between $F_{E V} V_{1.0}$ and PEF changes following Alupent inhalation after the shift with more pronounced effects on PEF. The coefficients of variation in $\mathrm{FEV}_{\mathbf{1 . 0}}$ and PEF measurements (by the Bernstein type spirometer and the Wright peak flow meter) proved approximately equal.
\end{abstract}

A variety of pulmonary function tests have been used for the diagnosis of obstructive respiratory disease. Although the measurement of airway resistance with the body plethysmograph is the best method for evaluating airway obstruction, the forced expiratory volume in one second $\left(\mathrm{FEV}_{1.0}\right)$ is now the most frequently used spirometric technique.

Along with these tests, the measurement of the expiratory peak flow (PEF) by the Wright peak flow meter (Wright and McKerrow, 1959) has been used increasingly by many authors in both clinical and epidemiological studies. Although it has been found to give results comparable to those obtained by more refined methods, the peak flow meter has been challenged because it records flows only over the very short time interval of $10 \mathrm{msec}$ at an early phase of expiration.

A good correlation between $\mathrm{FEV}_{1.0}$ and PEF in normal subjects and in patients with pulmonary disease has been obtained in the past by a number of authors, but the relationship between these two expressions of ventilatory function has not yet been studied in subjects exposed to hemp dust.

Fairbairn, Fletcher, Tinker, and Wood (1962) have found among Post Office employees a correlation coefficient of $\mathbf{0 . 6 8 2}$ for women and $\mathbf{0 . 8 0 6}$ for men. A better correlation $(r=0.94)$ was obtained by Lal, Ferguson, and Campbell (1964) in 95 subjects, of whom about half were normal and half had diffuse airway obstruction. Prime (1960) has stated that the PEF is better correlated with maximum ventilatory capacity $(r=0.867)$ than with FEV $_{1.0}(r=0.730)$. Higgins (1957) found a correlation coefficient of 0.86 between the PEF and the maximum breathing capacity in a random sample of elderly men who had never worked in dusty occupations.

There have been only a few studies in which subjects exposed to occupational hazards were included. Lockhart, Smith, Mair, and Wilson (1960) found a good correlation between FEV $_{\mathbf{0 . 7 5}}$ and PEF in subjects with chronic bronchitis, asthma, and emphy- 
sema $(0.81$ for men and 0.62 for women). They claimed a poor correlation in 16 flax workers with symptoms of byssinosis. Phillips (1966) found a correlation coefficient of 0.939 between $\mathrm{FEV}_{1.0}$ and PEF in miners without chronic bronchitis and 0.867 in miners with chronic bronchitis.

\section{Materials and methods}

A study of respiratory symptoms and respiratory function was carried out in 99 non-smoking female hemp workers. Their ages ranged from 18 to 51 (mean 34 ) years and the duration of exposure to hemp dust from 1 to 24 (mean 11) years. Our primary concern related to changes in $\mathrm{FEV}_{\mathbf{1 . 0}}$ and PEF during the work shift, the correltaion between PEF and $F_{E V}$ 1.0, and the correlation between changes in these parameters over the shift.

\section{Respiratory symptoms}

The respiratory symptoms (particularly chest tightness on Monday or any other day during the working week), medical history, occupational history, and smoking habits were recorded using a standardized questionnaire on respiratory symptoms (Schilling, Vigliani, Lammers, Valić, and Gilson, 1964).

Ventilatory function tests

The one-second forced expiratory volume was recorded by a Bernstein type spirometer. Five to seven minutes after $\mathrm{FEV}_{\mathbf{1 . 0}}$ measurements peak expiratory flow rates were measured with a Wright peak flow meter (Airmed Ltd., Harlow, England). The FEV 1.0 $_{\text {data }}$ were corrected to BTPS. Both tests were performed before the beginning and again at the end of Monday shifts. The highest of five readings of both FEV $_{1.0}$ and PEF were taken as the results.

In 25 workers with symptoms of byssinosis and 32 without byssinosis the $\mathrm{FEV}_{1.0}$ and PEF were recorded several times during the working hours: in the morning shift at 6 a.m. before the subjects had entered the mill, and again at 8 a.m., 9 a.m., 11 a.m. and 2 p.m. at the end of theshift (the others refused to be examined five times during the shift). The measurements were performed in the afternoon shifts at the same time intervals.

All the workers with symptoms of byssinosis were invited to take part in the trial of a bronchodilator aerosol. In the 21 volunteers the $\mathrm{FEV}_{1.0}$ and PEF tests were repeated as they came off shift and they were given orciprenaline ${ }^{1}$ by aerosol within 10 minutes of stopping work. The tests were repeated at intervals after the inhalation.

The results of the statistical tests were considered significant when the probability of obtaining the results by chance was less than 0.05 (1:20).

\section{Results}

The results of FEV $_{1.0}$ and PEF measurements in female hemp workers with and without byssinosis carried out before and after Monday shifts are presented in Table 1. Both byssinotic and nonbyssinotic workers suffered a significant mean reduction of $\mathrm{FEV}_{1.0}$ and PEF over the shift $(P<0.01)$. The reductions of both $\mathrm{FEV}_{1.0}$ and PEF were signifcantly greater in workers with symptoms of byssinosis $\left(\mathbf{P}<\mathbf{0 . 0 5}\right.$ in $\mathrm{FEV}_{\mathbf{1 . 0}}$ testing; $\mathbf{P}<\mathbf{0 . 0 1}$ in $\mathbf{P E F}$ testing). The relative mean reductions of PEF in both groups of subjects were higher $(25.8 \%$ and $16.0 \%$ respectively) than those of FEV $_{1.0}(16.7 \%$ and $12.7 \%$ respectively).

The correlation coefficient between PEF and FEV $_{1.0}$ before work was found to be +0.605 $(P<0.01)$ for subjects with symptoms of byssinosis and $+0.461 \quad(\mathrm{P}<0.01)$ for those without byssinosis.

Byssinotic hemp workers showing at the same time other respiratory symptoms (chronic bronchitis, asthma, or dyspnoea) had significantly greater reductions of both PEF $(P<0.01)$ and $\mathrm{FEV}_{\mathbf{1 . 0}}$ $(P<0.005)$ over the shift than those without such symptoms (Table 2). The mean acute reduction of FEV $_{1.0}$ and PEF over the work shift in hemp workers without byssinosis was not affected by the presence of non-specific respiratory symptoms $(P>0 \cdot 05)$.

The correlation coefficient between $\mathrm{FEV}_{1.0}$ and PEF changes over the shift for the whole group of hemp workers was $+0.654(\mathrm{P}<0.001)$. For subjects with byssinosis the correlation coefficient was slightly

1Orciprenaline (Alupent) and nebulizers were supplied by Messrs. C. \& H. Boehringer Sohn, Ingelheim, W. Germany.

TABLE 1

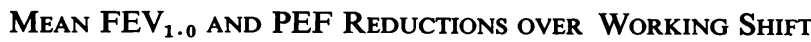

\begin{tabular}{|c|c|c|c|c|c|c|c|c|c|c|}
\hline Group & $\mathbf{N}$ & $\begin{array}{l}\text { Before } \\
(\mathrm{ml})\end{array}$ & $\begin{array}{c}\text { After } \\
(\mathrm{ml})\end{array}$ & $\begin{array}{l}F E V_{1.0} \\
\text { Reduction } \\
(m l) \quad(\%)\end{array}$ & $\mathbf{P}$ & $\begin{array}{l}\text { Before } \\
(\text { l/min })\end{array}$ & $\begin{array}{c}\text { After } \\
(\mathrm{l} / \mathrm{min})\end{array}$ & $\begin{array}{l}P E F \\
\text { Reduc } \\
\text { (l/min })\end{array}$ & $\begin{array}{l}\text { tion } \\
(\%)\end{array}$ & $\mathbf{P}$ \\
\hline \multirow{2}{*}{$\begin{array}{l}\text { With } \\
\text { byssinosis } \\
\text { Without } \\
\text { byssinosis }\end{array}$} & 39 & 2681 & 2234 & $-447^{1} \quad(16 \cdot 7)$ & $<0.01$ & 387 & 287 & $-100^{2}$ & (25.8) & $<0.01$ \\
\hline & 60 & 2729 & 2383 & $-346^{1} \quad(12 \cdot 7)$ & $<0.01$ & 388 & 326 & $-62^{2}$ & $(16 \cdot 0)$ & $<0.01$ \\
\hline
\end{tabular}

${ }^{1}$ Mean $\mathrm{FEV}_{1.0}$ reduction in byssinotics $(447 \mathrm{ml})$ significantly greater than in non-byssinotics $(346 \mathrm{ml})(\mathrm{P}<0.05)$

${ }^{2}$ Mean PEF reduction in byssinotics $(1001 / \mathrm{min})$ significantly greater than in non-byssinotics $(621 / \mathrm{min})(\mathrm{P}<0.01)$ 
TABLE 2

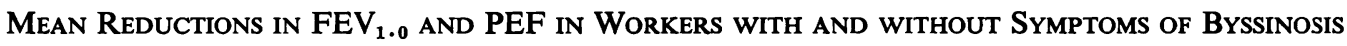

\begin{tabular}{|c|c|c|c|c|c|c|c|}
\hline \multirow[b]{2}{*}{ Group } & \multirow[b]{2}{*}{$N$} & \multirow[b]{2}{*}{$\begin{array}{c}\text { Mean } \\
\text { age } \\
(y r)\end{array}$} & \multirow[b]{2}{*}{$\begin{array}{l}\text { Mean } \\
\text { height } \\
(\mathrm{cm})\end{array}$} & \multicolumn{4}{|c|}{ Reductions } \\
\hline & & & & (litres) $^{F E V}$ & $(\%)$ & $(l / \min )^{P E}$ & $(\%)$ \\
\hline $\begin{array}{l}\text { With byssinosis } \\
\text { With respiratory symptoms }{ }^{1} \\
\text { Without respiratory symptoms }\end{array}$ & $\begin{array}{l}28 \\
11\end{array}$ & $\begin{array}{l}34 \\
29\end{array}$ & $\begin{array}{l}158 \\
158\end{array}$ & $\begin{array}{l}-0.495 \\
-0.323\end{array}$ & $\begin{array}{l}(17.9) \\
(14 \cdot 3)\end{array}$ & $\begin{array}{l}-113 \\
-68\end{array}$ & $\begin{array}{l}(27 \cdot 8) \\
(20 \cdot 1)\end{array}$ \\
\hline $\begin{array}{l}\text { Without byssinosis } \\
\text { With respiratory symptoms }{ }^{1} \\
\text { Without respiratory symptoms }\end{array}$ & $\begin{array}{l}26 \\
34\end{array}$ & $\begin{array}{l}37 \\
33\end{array}$ & $\begin{array}{l}157 \\
158\end{array}$ & $\begin{array}{l}-0.376 \\
-0.322\end{array}$ & $\begin{array}{l}(13 \cdot 8) \\
(10 \cdot 9)\end{array}$ & $\begin{array}{l}-67 \\
-\quad 59\end{array}$ & $\begin{array}{l}(17 \cdot 9) \\
(14 \cdot 6)\end{array}$ \\
\hline
\end{tabular}

${ }^{1}$ Chronic bronchitis, asthma, dyspnoea

FEV $_{1.0}$ reduction: with respiratory symptoms $v$ without respiratory symptoms

$\mathbf{P}<0.05$ in byssinotics; $\mathbf{P}>0.05$ in non-byssinotics

PEF reduction: with respiratory symptoms $v$ without respiratory symptoms

$\mathbf{P}<0.01$ in byssinotics; $\mathbf{P}>0.05$ in non-byssinotics

higher $(\mathrm{r}=+0 \cdot 725 ; \mathrm{P}<0.001)$ than for those without byssinosis $(r=+0.631 ; P<0.001)$. The difference between these two correlation coefficients was not statistically significant $(P>0.05)$.

Significant correlation coefficients between changes of FEV $_{1.0}$ and PEF over the work shift were found in byssinotic as well as in non-byssinotic hemp workers, with and without other respiratory symptoms (Table 3). The correlation was higher in the groups without respiratory symptoms in both byssinotics and workers without byssinosis, but these differences were not significant $(P>0.05)$.

TABLE 3

Coefficients of Correlation and LeVel of Significance between Changes In PEF AND CHANGeS IN FEV $_{1.0}$ OVER THE SHIFT

\begin{tabular}{l|c|c|c}
\multicolumn{1}{c|}{ Group } & $\mathrm{N}$ & $\mathrm{r}$ & $\mathrm{P}$ \\
\hline $\begin{array}{l}\text { With byssinosis } \\
\text { With other respiratory } \\
\text { symptoms }\end{array}$ & 28 & +0.631 & $<0.001$ \\
$\begin{array}{l}\text { Without other } \\
\text { respiratory symptoms }\end{array}$ & 11 & +0.777 & $<0.001$ \\
\hline Total & 39 & +0.725 & $<0.001$ \\
\hline $\begin{array}{l}\text { Without byssinosis } \\
\text { With respiratory } \\
\text { symptoms }\end{array}$ & 26 & +0.531 & $<0.01$ \\
$\begin{array}{l}\text { Without respiratory } \\
\text { symptoms }\end{array}$ & 34 & +0.723 & $<0.001$ \\
\hline Total & 60 & +0.631 & $<0.001$ \\
\hline
\end{tabular}

'Chronic bronchitis, asthma, dyspnoea

No significant difference between correlation coefficients (P>0.05).
Changes in $\mathrm{FEV}_{1.0}$ and PEF in the course of Monday work shifts were followed in 25 byssinotic female hemp workers and 32 female hemp workers without symptoms of byssinosis (Figure). There was a significant rapid decrease of both $\mathrm{FEV}_{1.0}$ and PEF during the first two to three hours of exposure to hemp dust in byssinotics and no significant changes during the latter part of the shift. In workers without byssinosis changes were taking place more gradually in the course of the whole shift. In both groups of workers the relative changes of PEF were more pronounced than those of $\mathrm{FEV}_{\mathbf{1 . 0}}$.

Orciprenaline administration after the shift in a group of 21 byssinotic subjects increased significantly both the $\mathrm{FEV}_{1.0}$ and PEF values $(\mathrm{P}<0.001)$, indicating that the ventilatory function reductions over the shift were at least partly reversible. The correlation coefficients between the increase of FEV $_{1.0}$ and PEF following the orciprenaline inhalation were $+0.746(\mathrm{P}<0.001)$ for the whole group, $+0.567(\mathrm{P}<0.001)$ for byssinotics with, and $+0.845(\mathrm{P}<0.001)$ for byssinotics without other respiratory symptoms (chronic bronchitis, asthma, and dyspnoea).

\section{Discussion}

Significant acute reductions of $\mathrm{FEV}_{1.0}$ and PEF over Monday shifts confirm the acute effects of soft hemp dust on the bronchial muscles as described earlier (Valić, Žuškin, Walford, Keršić, and Pauković, 1968; Valić and Žuškin, 1970). The relative changes of PEF were more pronounced than those of FEV 1.0 . The difference in the PEF reduction between subjects with and without byssinosis was slightly greater than the difference in the $\mathrm{FEV}_{\mathbf{1 . 0}}$ reduction. The subjects with byssinosis had a $10 \%$ greater mean 


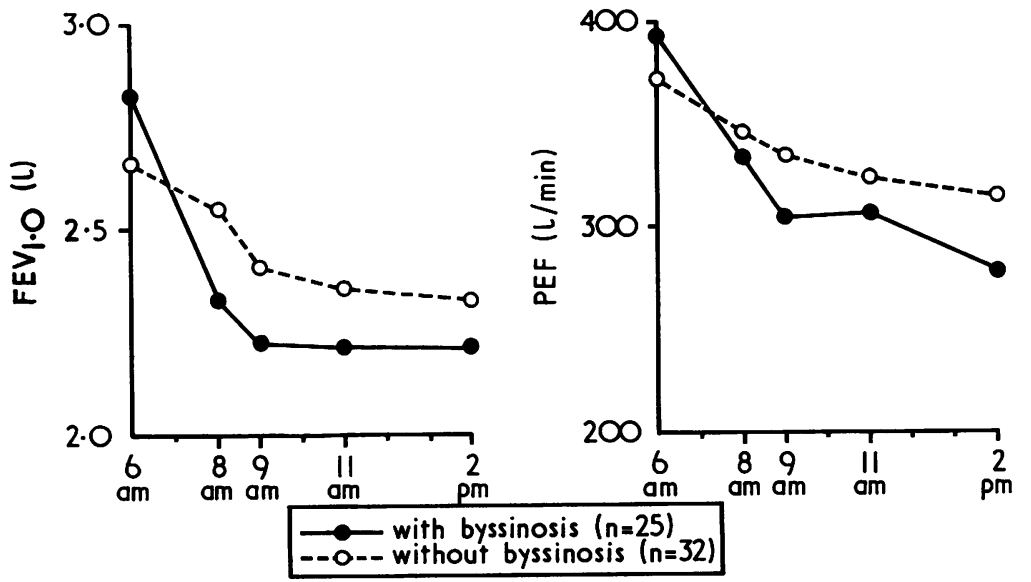

FIGURE Mean changes in $\mathrm{FEV}_{1.0}$ and PEF during the shift in workers with and without byssinosis.

reduction in PEF and a $4 \%$ greater mean reduction in $\mathrm{FEV}_{1.0}$ than those without byssinosis.

Evidence was obtained of a significant positive correlation $(P<0.01)$ between PEF and FEV 1.0. $^{\text {. The }}$ correlation coefficient was slightly but not significantly higher $(\mathrm{P}>0.05)$ for subjects with byssinosis $(+0.725)$ than for subjects without symptoms of byssinosis $(+0 \cdot 631)$. These values are in good agreement with those reported by Simonsson (1963) in his obstructive and restrictive groups but lower than those obtained by Leiner, Abramowitz, Small, Stenby, and Lewis (1963) in subjects with obstructive pulmonary changes $(r=+0.903)$.

Our results suggest a gradual fall of PEF and FEV $_{1.0}$ during the shift in hemp workers, similar to that found by McKerrow, McDermott, Gilson, and Schilling (1958) in their studies of cotton workers. The reductions in both PEF and FEV, ,o were more rapid in byssinotics (Figure).

As a consequence of the orciprenaline administration at the end of the shift there was always an increase in both FEV, ${ }_{1.0}$ and PEF; the improvement was greater in PEF. Similar observations were reported by Simonsson (1963) who found PEF to be more sensitive to the inhalation of a bronchodilator than FEV $_{1.0}$. Ritchie (1962) also indicated a significantly greater relative response in PEF. A significant correlation between the change in PEF and the $\mathrm{FEV}_{1.0}$ change after isoprenaline $(r=0.52)$ was obtained by Saunders (1967).

Bouhuys $(1957,1960)$ claimed that the determination of the maximal expiratory flow rate (with a Lilly's pneumotachograph) was much less reliable than the measurement of the volume expired in one second because of a greater variability in maximal expiratory flow rate measurements. The coefficient of variation of PEF measurements was reported to vary from $13 \cdot 1 \%$ (Shepard, 1962) to $30 \%$ (Lockhart et al., 1960). In our study the coefficient of variation of PEF results calculated for each subject in a group of 32 hemp workers varied from 1 to $14 \%$, and that of $\mathrm{FEV}_{1.0}$ from 1 to $15 \%$. These data suggest that there is no difference in the variability of PEF and FEV $_{1.0}$ measurements (if PEF is measured with the Wright peak flow meter and $\mathrm{FEV}_{\mathbf{1 . 0}}$ with the Bernstein type spirometer).

On the basis of our results we could not support the claim that the measurement of the maximum expiratory flow rate is less sensitive than that of the forced one-second expiratory volume in the epidemiological assessment of obstructive pulmonary changes in hemp workers. The relative acute reductions of PEF over the work shift in soft hemp dust exposure were proved greater than those of $\mathrm{FEV}_{\mathbf{1 . 0}}$ in subjects both with and without byssinosis (Table 1). The difference in the mean ventilatory function between byssinotic and non-byssinotic hemp workers was more pronounced in PEF than in FEV $_{\text {1.0. }}$. A significant positive correlation coefficient was found between PEF and FEV 1.0 changes over the shift (Table 3). The coefficient of variation in PEF and FEV $_{1.0}$ measurements proved approximately equal. Taking into account these findings and an easy transportability of the apparatus, owing to its low weight and volume on the one hand, and its simple handling and low cost on the other, the Wright peak flow meter can well be used for epidemiological surveys.

This investigation was supported in part by grant (PL 480 Project 02-006-3) from the Bureau of Occupational Safety and Health, US Public Health Service, Department of Health, Education and Welfare. 


\section{References}

Bouhuys, A. (1957). The clinical use of pneumotachography. Acta med. scand., 159, 91-103. (1960). Peak-flow meter. Brit. med. J., 1, 1209.

Fairbairn, A. S., Fletcher, C. M., Tinker, C. M., and Wood, C. H. (1962). A comparison of spirometric and peak expiratory flow measurements in men with and without chronic bronchitis. Thorax, 17, 168-174.

Higgins, I. T. T. (1957). Respiratory symptoms, bronchitis, and ventilatory capacity in random sample of an agricultural population. Brit. med. J., 2, 1198-1203.

Lal, S., Ferguson, A. D., and Campbell, E. J. M. (1964). Forced expiratory time: a simple test for airways obstruction. Brit. med. J., 1, 814-817.

Leiner, G. C., Abramowitz, S., Small, M. J., Stenby, V. B., and Lewis, W. A. (1963). Expiratory peak flow rate. Standard values for normal subjects. Use as a clinical test of ventilatory function. Amer. Rev. resp. Dis., 88, 644-651.

Lockhart, W., Smith, D. H., Mair, A., and Wilson, W. A. (1960). Practical experience with the peak flow meter. Brit. med. J., 1, 37-38.

McKerrow, C. B., McDermott, M., Gilson, J. C., and Schilling, R. S. F. (1958). Respiratory function during the day in cotton workers: a study in byssinosis. Brit. $J$. industr. Med., 15, 75-83.

Phillips, T. (1966). The forced expiratory volume and the peak expiratory flow rate in pneumoconiosis. Brit. J. Dis. Chest, 60, 197-199.
Prime, F. J. (1960). Peak-flow meter. Brit. med. J., 1, 423.

Ritchie, B. (1962). A comparison of forced expiratory volume and peak flow in clinical practice. Lancet, 2, 271-273.

Saunders, K. B. (1967). Bronchodilator response patterns in patients with chronic airways obstruction: use of peak inspiratory flow rate. Brit. med. J., 2, 399-402.

Schilling, R. S. F., Vigliani, E. C., Lammers, E., Valić, F., and Gilson, J. C. (1964). A report on a conference on byssinosis. In Proc. XIV int. Congr. Occup. Hlih, Madrid, 1963, Vol. 2, pp. 137-145 (Excerpta med. Int. Congr. Ser., No. 62).

Shepard, R. J. (1962). Some observations on peak expiratory flow. Thorax, 17, 39-49.

Simonsson, B. G. (1963). Dynamic spirometry studies in patients with lung disease. II. "Peak expiratory flow" as a measure of ventilatory capacity: value in pharmacological tests. Acta allerg (Kbh.), 18, 340-352.

Valić, F., and Žuškin, E. (1970). Arch. environm. Hlth, in press.

_-,$\frac{1}{-}$, Walford, J. Keršić, V. and Pauković, R. (1968). Byssinosis, chronic bronchitis, and ventilatory capacities in workers exposed to soft hemp dust. Brit. J. industr. med., 25, 176-186.

Wright, B. M., and McKerrow, C. B. (1959). Maximum forced expiratory flow rate as a measure of ventilatory capacity, with a description of a new portable instrument for measuring it. Brit. med. J., 2, 1041-1047.

Received for publication May 12, 1970. 